\title{
International Watercourse Law and A Perspective on Nepal-India Relation
}

$\mathbf{T}$

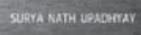

This book is written by a prominent person with more than three decades of experiences and expertise in the sector of water resources. Nepal's water resources have a very high potential to benefit the people of this region; which is not happening in practice. The people of this region have a right to know, why the water resources of Nepal have not been fully exploited - asserts the author. The book tries to answer this query. The book reviews the water relationship between Nepal and India in the perspectives of International Law. The author has analyzed in detail the various aspects of the Kosi, Gandak agreements and the Mahakali River Treaty between Nepal and India. In the considered opinion of the author, Nepal has failed miserably to benefit from Nepal-India bilateral agreements.

The book has two parts: a) International law, and b) Nepal-India Cooperation on water resources. The Appendices include Rules and Laws on International Rivers/water courses, agreements on the Kosi, Gandak rivers and the Treaty on the Integrated Development of the Mahakali River.

Chapter 1: Introduction:- In the first part there are two Chapters, Chapters 2 and 3.

Chapter 2: International Water Law:- It deals with the various laws on the international rivers/water courses. It explains the Helsinki Rules on the uses of Water of International Rivers, and Convention of the Nonnavigational Uses of International Water Courses. India has not signed this convention. Further, it is not yet adopted by the UN due to lack of sufficient number of signatories. Though, India has not signed the Convention, it has a moral obligation to follow the laws. The basic feature of the International Law on Watercourses is Equitable utilization within border, and No significant harm to other countries. The Author has described the Regional Convention regarding the international watercourse in Africa, Americas, and Europe. Treaties dealing with the agreements between the USA and Canada, Bulgaria and Turkey, Lesotho and South Africa, Mekong River Commission, Nile Water, Columbia River, The Indus Basin, Bangladesh and India are discussed in detail. In addition it gives the decisions of International or national Courts or Tribunals on 15 cases of Disputes. It has given description of International Legal agencies in the sector. The Indian Arbitral Awards are cited as good examples for resolving disputes.
The author's point of view is that adherence to the International Laws by India and Nepal will benefit both the countries, and as such there will not be any sense of cheating between them.

Chapter 3: Laws on Procedures of Cooperation in International Water Courses:- The following points are covered in this Chapter:

1. Obligation to Notify about Planned Measures;

2. Obligation to Exchange Information;

3. Obligation to Consult and Negotiate in Good Faith;

4. Issues Connected to Obligations to Exchange Information's in Good Faith;

5. Issues connected to Obligations to Exchange Information, notify Planned Measures and Negotiate in Good Faith;

6. Silence to Notifications and Reservation to Future use;

7. The World Bank Policy on the Use of International Water courses; and

8. Benefit Sharing among the Watercourse States.

Chapter 4: Nepal's Water Resources:- The author cites that the 138.5 Billion $\mathrm{m}^{3}$ of water storage behind high dams in Nepal will be vital to India for irrigating its land in the light of increased population, climate uncertainty, and transfer of water in deficit states. Climate change will decrease the water flows considerably. Further, the acute shortage of electricity in India's Northern Grid can be alleviated to a great extent from the high value peaking hydropower from the storage projects in Nepal.

Nepal's interest should be to have rightful access to the sea through water transports via the Ganges through the water resources development of Nepal.

Chapter 5: Agreement on the Kosi Project:- It sheds light on how the lease period of 99 years was changed to 199 years that was bargained politically in the highest level. The benefits accrued to Nepal are negligible compared to the benefits to India. Due to poor monitoring by Nepal, it has not been able to get the concessions that were agreed in the agreement. For example, compensation has not been paid to the land owners of 10,00o Bigha ( 6250 ha) even after 58 years have elapsed, the land tax has not been fully paid to the Government of Nepal for a long time, royalty for the hydropower sold in India (generated from the project) has been neither asked by Nepal nor paid by 
India. The breach of the Left Kosi Embankment in 2008 created havoc and misery to millions of people in Nepal and India. It was the responsibility of the Government of India for the maintenance and safe operation of the Kosi Barrage complex including the embankments. And it was India's responsibility to rehabilitate the infrastructures and the people after the catastrophic flood. However, the Government of Nepal had to repair the road and conduct other rehabilitation works; and compensation was not demanded from India for the loss and suffering of the Nepalese people.

The book discusses about the proposed Kosi High Dam Project (KHDP) for which investigation is ongoing. The author is concerned that the Nepalese counterparts in the Study Team are paid salary by India; and, hence, they will not be effectively working for the interest of Nepal and they may be the mere witness of the Study. No office has been established for the study of navigation and irrigation benefits in the Indian Territory.

The author's view point on the KHDP is that India desperately needs it to be executed in earnest. For this Nepal should be adequately compensated and the benefits generated by the regulated water downstream should be evaluated and shared because about $100 \mathrm{sq}$ miles of Nepal land will be submerged, and hundreds of thousands of people will be displaced and need to be rehabilitated in Nepal. The author suggests striving to get the benefits as royalty similar to Lesotho getting benefits from South Africa or Canada getting downstream benefits of the Columbia River project between the USA and Canada. Further, it will be in Nepal's interest to make provisions for ensuring a rightful way to gain access to the sea through water transport.

The author has not mentioned that the intention of the KHDP is to construct two very long canals; one of them to link Mechi River in the east (Kosi - Mechi Link canal). Its DPR is already prepared by the state of Bihar and approved by the Central Govt. of India. Another is the link to enter India near Birgunj of Nepal that will gobble up very large farmland of Nepal's Terai which is the bread basket of the country.

Chapter 6: The Gandak Project Agreement :- The author perceives that the agreement was conceived, designed and implemented for fulfilling the requirement of India. Even small benefits allowed in the agreement are never honestly implemented, i.e. the agreed 850 cusecs of water for the Nepal Eastern Canal and agreed quantity of water for Nepal Western Canal were never supplied in full capacity. In the Eastern Canal, the water release was only $56 \%$ (World Bank's average figure) of the 850 cusecs in the 1980s. Further, there is a provision of water transport for Nepal in the agreement for access to the Ganges. However, nothing has happened so far in this regard.

Chapter 7: Treaty on the Integrated Development of the Mahakali River:- The Author was also a member of the Negotiating Team with India on this Treaty; and hence, the author had first hand information on the subject. The author has analyzed in detail all aspects of the Treaty. It is a combined Treaty of the Sharada barrage, Tanakpur barrage, and the Pancheshwar Multipurpose project (6480 MW). In Nepal, this treaty attracted many street protests, political maneuvers, and was ultimately ratified by the parliament with a two third vote.

Like in other agreements, the agreed benefits are not extended to Nepal such as release of 10 cumecs of water for Dodhara Chadani (Nepal's territory) by India; India says that this provision is applicable only after completion of the Pancheshwar project, lowering the higher sill level provided for release of water to Nepal in the Tanakpur barrage has been put on limbo. The water of the Mahakali River at the Pancheshwar dam site was apportioned to half to Nepal and half to India without prejudice to their respective existing consumptive use of the waters of the Mahakali River. It is not clear about the meaning of this phrase. Is it the 50:50 for both countries so that it should not be less than the existing consumptive use of each country; or the total existing consumptive use is deducted and the remaining water is 50:50 for the two countries. Further, there is also a provision in the Exchange of Letters that no party will claim the unutilized portion of the Mahakali water. Many scholars interpret the meaning of these two points as harmful to Nepal. However, the author seems confident of Nepal getting a fair share. Further, there is a provision of the avoided cost principle for determining the price of the exported electricity to India. Experts believe that the export price needs to be based on the peaking value of the generated electricity from the storage project.

Sixteen years have passed, and the much anticipated Detailed Project Report (DPR) said to be completed within six months in the Treaty is far from completion. There is never ending negotiation between the two countries on this project. This project and also the Koshi High Dam project may receive much lip-service during up-coming general election in India.

\section{Chapter 8: Understanding India's Approach} to the Development of Water Resources in the Region:- This is the most important chapter of this book. The basic Indian approach has been first to construct without consultation, and later negotiate if necessary. The author has listed eight points on India's approach. These are: no regionalization, deal only bilaterally; engage in all projects but advance only those projects which primarily serve India's interests; delink hydropower from water resources; try to gain maximum control over the resources directly or indirectly; avoid generalization of policy so as to not to make it a precedent; continue engagement in project wise basis; proactively create favorable internal situations in the neighboring countries that is favorable for deal making 
on the part of India ${ }^{1}$; and to continue to exert leverages on the deals on water resources. The author rightly questions Indian approach and opines that such an approach is harmful to India as well. In the author's view, India needs to be open and have a liberal attitude to accommodate the interests of all the countries in the region.

Chapter 9: Conclusion and Recommendations:This chapter deals with the strategy Nepal should follow, course of policy and action for future. This chapter has dealt with the subject of electricity export, and Nepal's desire of India extending facilities for easy access to Bangladesh. In addition, he advises to get even the small benefits to Nepal as agreed in the Kosi, Gandak and Mahakali agreements before negotiating further with India.

The author recommends taking up projects without hesitation that are in the interest of Nepal. And he argues that a better served Nepal can only be relied upon and be competent enough to negotiate an enduring treaty with India.

It is a good book and a must read for decision and policy makers of Nepal or anyone interested in the field of water resources development of Nepal. It will also be equally useful for the officials in the regional countries, and for the US and Chinese officials to critically understand the Indian water attitude.

Another Reviewer of the Book Dr. Yuba Raj Sangraula has greatly praised the book and suggests that "This Book needs to be immediately incorporated by universities as $a$ "reference book" in their syllabus." He rightly thinks that this Book is a milestone to correct India-Nepal Bilateral relations and make it a pragmatic and mutually beneficial one.

The author deserves a grateful thank you for his hard and sincere work in his extensive research and writing this brilliant book.

In conclusion, it is worth to quote Dr. Upendra Gautam, a founding member of JVS and president of CMS, the institutional partner of GWP Nepal, who summarizes the book thus, "The greatest merit of the book lies in providing a wider regional or Himalayan perspective to Nepal-India cooperation in the framework of international water law. Conclusion of such a perspective is that the optimum beneficial conservation and harnessing of water lie in greater regional cooperation."

\section{Notes}

1. Most people believe that abolition of Ministry of Water Resources in Nepal was such an internal move duly promoted by the Indian design. 